\title{
Financial Management Skills and Affordability of Housing in Nakuru County
}

\author{
Stella Cheraisi Korir* \\ School of Business and Economics, Kabarak Univerity, Nakuru, Kenya \\ P.O.Private Bag 20157 \\ Patrick Kibati \\ School of Business and Economics, Kabarak Univerity, Nakuru, Kenya \\ P.O.Private Bag 20157 \\ John Kipkorir Tanui \\ School of Business and Economics, Kabarak Univerity, Nakuru, Kenya \\ P.O.Private Bag 20157
}

The research is financed by Asian Development Bank. No. 2006-A171(Sponsoring information)

\section{Abstract}

This study sought to determine the relationship between financial management skills and house affordability. The study adopted positivist, cross sectional design to collect, analyze and make conclusions on the relationship between the two variables. Heads of households were identified as the respondents in this study, where us each household was considered as unit of analysis. Research data was collected through structured questionnaires and interview guides. Data was collected from 384 households in London, Kaptembwa, Kapkures, Rhonda, Shaabab, Biashara, Kivumbini, Flamingo, Menengai and Nakuru East wards within Nakuru East and Nakuru west subcounties. Results from the study revealed that financial management skills are a significant determinant of house affordability. In fact, it was evident that financial planning, budgeting, expenditure and financial control among other skills are very critical in the journey towards house ownership. The study recommends that individuals should enhance financial management skills through trainings and seminars. Financial institutions, as well as the government can support the households by organizing training opportunities, especially for low income households. The study recommends that further study should focus on financial management areas that are key to low income households and how such skills can be used towards house ownership

Keywords: Financial Management Skills, Housing Affordability, Nakuru County

DOI: $10.7176 /$ RJFA/12-20-05

Publication date:October $31^{\text {st }} 2021$

\section{Introduction}

The conversation around house affordability is very popular among individuals, households, investments and even the government. This is because, to an individual, access to a decent home is a basic need and a right. To a household, the general wellbeing of a household largely lies on its habitat, a home. To the government, affordable and decent housing is one of the key indicators of social and economic wellbeing.

In most nations, the issue of access to affordable and decent housing is still emotive. This is largely because, the individual households are largely unable to acquire or access decent and affordable houses, either because they are too expensive for them or the households just do not have the capacity to acquire or rent one [3]. While most governments put measures to have a planned strategic way to deal with the housing issue, generally, achievement of adequate affordable and decent hosing still remains far from realization to most governments [24]. This is largely attributed to the fact that while housing is resource intensive, the rate of population growth is on the rise, especially in urban areas, due to rural urban migration in search of opportunities.

In Kenya, the housing problem is so big that the efforts can be seen in all levels, starting from individuals, investment organizations, religious organizations, and non-governmental organization to the government and sometimes even to international development partners [9]. In fact, to reducing the housing problem in the country, the government has put affordable housing as one of the main agenda in the next five years [10]. Among other factors identified empirically to influence house affordability is the financial management skills [2, $11,14]$. It is on this ground that this study examines the relationship between financial management skills and house affordability in Nakuru County.

\section{Literature Review}

\subsection{Financial Management Skills}

Financial management skills are the financial competencies necessary in organizing and controlling financial activities and resources [8]. Financial management skills are useful in estimation of capital requirements of a 
housing plan. Such skills are used in determination of capital composition of potential financing options and thus facilitate choosing of sources of funds. According to the [6], right financial management skills promote housing affordability. This is because, one is able to analyze available financing options and consequently make informed investment decisions.

In a study by [17] on the role of financial management training and housing, it was evident that individuals lacking the right financial skills are likely to end up burdening financial obligations like housing loans as they lack adequate information on loans and its products. Such individuals are likely to make misinformed financial decisions that result into strained financial lives. Individuals with low financial skills are more likely to go for expensive financing options or expensive housing plans as compared to counterparts with such skills [4].

\subsection{Housing Affordability}

Housing affordability is concerned with acquisition of a house at the preferred loca-tion, ideal size and a house with all the desired features. Housing affordability remains a big challenge to majority of households, including in developed nations. In the United Kingdom, only $65 \%$ of the individuals have access to decent and affordable homes [13]. In Malaysia, less than 50\% of residents have access to affordable housing [4] while in South Africa, $20 \%$ of the citizens mainly invested in short term projects and are therefore miles away from achieving affordable homes.

To some extent, the cost of housing and consequently, affordability of housing is a question of demand and supply. In the last decade, most economies have seen growth in populations, especially in urban areas, occasioned by rural-urban migration in search of opportunities. Such influx of people in urban areas leads to demand for housing going way beyond supply [5]. The excess demand may to a large extent lead to higher cost of housing as seen in most markets.

In most nations, cost of housing is on the rice. For instance, in Ethiopia, [3] indicates construction cost of a three roomed house is ranging between $\$ 15,000$ - $\$ 20,000$, an amount considered unaffordable by a majority of Ethiopians. The average cost of similar house in Nigeria is approximately USD 27,000, a reality that has seen most households, especially those in the low income bracket living in unhealthy conditions. Closely tied to the cost of construction, is the cost of valuation. Values have in-creasingly become unnecessarily expensive. In Uganda, the average cost for valuation is USD 470, which means the cost of housing has to go put by the same amount as long as valuation is incorporated. This amount is beyond reach for most households [2], while in Ghana, fully contained house range from USD 50,000 and USD 110,000. Actually, in Ghana, the high cost of housing is blamed for lack of proper housing, especially for low income households.

In Kenya, access to affordable housing still remains a dream among majority of low and middle-income households. While over $70 \%$ of residents in urban areas rely on rental housing, rental housing can only satisfy $60 \%$ of such needs. Coupled with the problem of adequate housing supply, low income and inadequate financial supply limits access to investments towards affordable housing programs available [23]. Financial mortgage and loans skills are very low in the country that has translated to poor housing as housing affordability is a long-term investment. In addition, most financing models in Kenya are limited in scope and the financing models normally excluded the middle and low income households. This has resulted in poor financial skills especially on loans and mortgage that would otherwise promote housing affordability [24].

\subsection{Empirical Review}

Study by Mulliner (2017) in the United Kingdom on housing affordability among the low income earners in the country found that the housing affordability is dependent on the financial management skills especially to the low-income earners. The study also found that most of the low-income earners in the country lack financial saving skills that can explain the lack of proper housing. In a related study on financial barriers to investment in affordable housing, [6] showed that housing investment decisions are largely influenced by financial management skills. Middle and high income dwellers, who have better financial management exposure exhibit better housing investment decisions [7]. The low income earners, with little financial management exposure cannot effectively sustain mortgage repayment due to lack of skills in financial management [4].

In Australia [6] identified financial management expertise as significant factor in access to affordable housing. The study showed that the low number of financial management experts in Australians has significantly contributed to low level of home ownership in the Nation. The study recommended that individuals need to be trained possible investment options, the costs associated and repayment and associated implications. Focusing in Malaysia, [5] identified incompetence on housing loan options and housing schemes policies as the main hindrance to affordable housing in the country. Inadequate knowledge of such options and policies presented itself as a strong hindrance. The study revealed that there is low borrowing awareness when dealing with housing loans in the country.

Study by [10] on financial education and affordability of housing among the house-holds with low income showed that $41 \%$ of the adults in San Francisco struggled to master personal management skills as most were 
struggling with personal finances. Personal financial management skills like saving, budgeting and credit and debit were identified in the study as factors that could enhance realization of affordable housing. Inadequate financial management kills, especially among low-income earners is associated with low savings and investment. With low savings and investment, housing affordability remains just but a dream [7].

According to [18], the relationship between financial management skills and housing affordability is evident in different cities, including, Moscow, Brazil, Mexico, Argentina and Mozambique. Most of the big cities are just towards achieving their housing affordability plans, with large number of residents still not living in houses without the desired features nor suitable locations [3]. The study found that housing affordability is steadily raising, thanks to proper budgeting and financial management programs. Developed nations have better housing achievements than developing nations due to the long term budgeting and financial management competence.

According to [16] most African nations due to reliance on indigenous financial management practices were very slow in their journey towards affordable housing. The study observed that concluded that Africa need to change on the indigenous financial practices for it to realize housing affordability. Study by [10] assessed importance of money management skills, in a study based in South Africa and reported that financial behavior such as unplanned credit purchasing and lack of control of expenditure are outcomes of inadequate financial management skills. The study further reported that lack of controlled expenditure is associated with low savings and consequently low investment in long term projects like housing.

A survey on potential in the housing sector and with focus on financial management skills in Nigeria revealed a significant relationship between financial management skills and housing affordability. The study further recommended that low income earners in the country needed to develop their financial skills especially on financial planning and saving skills to achieve housing affordability [16]. A separate study in the same area by [1] showed that inadequate financial management skills contributed significantly to poor housing delivery. In fact, the showed that inadequate financial skills has become a matter of interest to stakeholders and that there are concerted efforts by government and commercial banks equip citizens with the right financial skills which can enable one acquire a house. There is need for proper saving skills to make sure that small amount earned can give them a house in future or promote credit repayment of the government given accommodation [2].

In acknowledging the role of financial skill in affordable housing accessibility, the study of [1] sampled 113 households in Uganda to analyze the influence of financial skills on house affordability. The study showed that book keeping financial skills are significant in basic financial management towards long term investment plans such as housing. The study ascertained that having a proper house in terms of location and size is a long-term investment that needs proper planning. Findings of the study are consistent with those of [14] that focused on factors influencing housing affordability in Kenya. The study that collected data from 390 households revealed that loan acquisition is significantly influenced by financial skills. According to the study most of the lowincome individuals lack proper loan and mortgage skills that would have promoted acquisition of their own homes. The study concluded that lack of financial skills and the dynamic changes of mortgage and loans had significantly contributed to housing affordability in Nairobi.

\section{Research Methodology}

This study adopted positivist research approach. Positivist approach advocates for findings and conclusions made based on empirical analysis and hypothesis testing done of survey data [21]. Cross sectional, correlational survey design was used in this study to enable a snap shot analysis of the relationship between the research variables based on primary data. The study was based in Nakuru East and Nakuru West Sub-Counties. The two sub counties have 392,587 households, which constitutes the unit of analysis in this study. Random stratified sampling was used to arrive at a sample size of 384. The formula below was applied in sampling [15].

$s=\frac{Z^{2} p(1-p)}{c^{2}}$;

Where

s - Sample size

Z - Z-value (1.96 for a $95 \%$ confidence level)

$\mathrm{P}=$ Percentage of population picking a choice, expressed as decimal

$\mathrm{C}=$ Confidence interval, expressed as decimal (e.g., .05 $=+/-5$ percentage points)

Proportionate sampling was used to ensure all households are adequately represented in terms of wards. Barut, London, Kaptembwa, Kapkures, Rhonda, Shaabab wards for Nakuru town west and Biashara, Kivumbini, Flamingo, Menengai, Nakuru East for Nakuru town east were used as strata for purposes of sampling.

The study relied on primary data collected through questionnaires and interview. Questionnaires were selfadministered, alongside the interviews within a period of three months. Prior to data collection, the data collection tools were checked for validity and reliability through a pilot study. Conditions for validity and reliability were met. Similarly, the researcher ensured all authorization was sought before data collection. 
Collected data was checked for completeness before analysis, after which descriptive analysis was used to describe the research variables (financial skills and house affordability). Collected data was them coded and keyed into SPSS for purposes of analysis. The research variables were summarized through descriptive analysis while the relationship between the variables was sought through inferential analysis. Research findings were presented using tables, accompanied with interpretation and discussion. The study observed high level of integrity and ethics, ensuring respondents' integrity is upheld.

\section{Discussion}

Out of the 384 questionnaires administered, 333 questionnaires were successfully filled and returned for analysis. This was $87 \%$ response rate, considered very sufficient for analysis [22].

\subsection{Findings}

This study collected data from 333 households, with household heads serving as respondents. Table 1 shows distribution of respondents by gender and education.

Table 1. Distribution of respondents by Gender and Education

\begin{tabular}{lll}
\hline Gender & Frequency & Percent \\
\hline Male & 215 & 64.6 \\
Female & 118 & 35.4 \\
\hline Education & Frequency & Percent \\
\hline None & 11 & 3.3 \\
Primary & 58 & 17.4 \\
Secondary & 112 & 33.6 \\
Certificate & 73 & 21.9 \\
Diploma & 57 & 17.1 \\
Graduate & 19 & 5.7 \\
Postgraduate & 3 & 0.9 \\
\hline
\end{tabular}

Nakuru County are headed by males. This is consistent with the African culture and most religions that men are the head of the family. Study sought to establish the highest level of education of the respondents. The findings also affirm the notion that males serve as economic pillars in most households. The findings also revealed that nearly a half of the respondents did not have post-secondary school education. This implies that close to half of the population in Nakuru County do not have formal employment, and therefore may not access long term bank loans and mortgages.

\subsubsection{Descriptive analysis on Financial Management Skills}

The study collected and analyzed data financial management skills among the heads of households involved in the study. The findings were as presented in table 2 .

\section{Table 2. Descriptive analysis on Financial Management Skills}

\begin{tabular}{lll}
\hline Statement & Mean & Std. Dev \\
\hline I do not have skills on strategies of savings & 4.09 & 0.745 \\
I do not have skills on how to control expenditures & 4.01 & 0.827 \\
I do not have financial planning skills & 3.88 & 0.991 \\
I do not have knowledge on financial obligations towards acquiring a house & 3.94 & 1.009 \\
I do not have skills on book keeping & 3.89 & 0.913 \\
I do not have financial risk analysis skills & 3.95 & 0.820 \\
I do not examine my cash flows & 4.11 & 0.835 \\
I do not prepare budgets for my income & 3.89 & 0.977 \\
\hline Composite Scores & $\mathbf{3 . 9 7}$ & $\mathbf{0 . 8 9 0}$ \\
\hline
\end{tabular}

Findings in table 2 above reveal that household heads generally have inadequate skills on strategies of savings $(\mathrm{M}=4.09 ; \mathrm{SD}=0.745)$. The household heads generally have inadequate skills in financial planning and expenditure control as evidenced by means of 4.01 and 0.827 and standard deviations of 0.827 and 0.991 respectively. Interestingly, while the dream to own a home is shared among the respondents, there was lack of knowledge on financial obligations towards acquiring a house as evidenced by $\mathrm{M}=3.94$ and $\mathrm{SD}=1.009$. The household heads did not have adequate book keeping and financial risk analysis skills, necessary for investments towards house ownership as evidenced by high means of 3.89 and 3.95 standard deviations of 0.913 and 0.820 . Lastly, it was evident that the household heads did not have skills that could enable them examine cash flows as well as budget their income as evidenced by $(\mathrm{M}=4.11,3.89$ and $\mathrm{SD}=0.855,0.977)$.

From the interview, it was evident that most of the low income earners have not yet embraced the saving culture and this has greatly affected their housing challenges. Thy however recognized that saving can enable one, especially the unemployed, to obtain loans which can enable them afford a house. It was also evident that financial planning is one of the challenges that limit low income earners in owning a house and especially those 
who are not much educated.

The findings are consistent with those of [6] that in most households, there is general lack of financial management skills, and this generally limit knowledge on the available opportunities in as far as house affordability is concerned. Similar findings were reported by [14] who found that most low-income earners lacked the basic knowledge for them to save and invest. According to [11], saving is the most effective tool that low income households can use as key enablers to housing affordability; it is the only sure way to build financial credibility to a financial or investment institution.

\subsubsection{Housing Affordability}

The household heads were requested to respond to questionnaire items on housing affordability. The responses were summarized as presented in table 3 .

Table 3. Descriptive Analysis on Affordability of Housing

\begin{tabular}{lll}
\hline Statement & Mean & Std. Dev \\
\hline I cannot afford to build a house with desired features & 4.03 & 0.859 \\
I cannot afford to rent a house with desired features & 4.06 & 0.850 \\
I cannot afford to build a house that can accommodate my family members & 3.94 & 0.978 \\
I cannot afford to rent a house that can accommodate my family members & 3.90 & 0.977 \\
I cannot afford to build a house in a desired locality & 3.92 & 0.859 \\
I cannot afford to rent a house in a desired locality & 3.95 & 0.991 \\
\hline Affordability Index & $\mathbf{3 . 9 7}$ & $\mathbf{0 . 9 1 9}$ \\
\hline
\end{tabular}

The findings in table 3 indicated that house affordability still remains a dream for most households in Nakuru County. Majority of households are unable to acquire their desired homes, neither by building/purchasing nor via renting as evidenced by high means of 4.03 and 4.06 and standard deviations of 0.859 and 0.850 respectively. Similarly, majority of households cannot build, buy or rent a house that can accommodate their families as evidenced by the means of 3.94 and 3.90 and standard deviations of 0.978 and 0.977 respectively. Lastly, most households cannot afford to build/buy or rent a house in their desired locality as evidenced by means of 3.92 and 3.95 and standard deviations of 0.859 and 0.991 .

From the interviews, it was evident that home ownership is a priority for most households. Most respondents expressed that they are keen on the house features, size and location. While it was evident that some households were very far from achieving the dream of home ownership, majority of the respondents had strong desire to achieve the dream of home ownership.

The findings from this study are consistent with those of [12] that while it is the desire for every family to own a home adequate to accommodate all family needs, home ownership remain to be a dream for most families. The findings are also in agreement with the findings of [11] who established that house features, size and location are the key factors that influence choice of a house. According to [4], while many families desire to rent or own desired homes, the affordability question remains the biggest challenge to households in a bid towards home ownership.

\subsubsection{Financial Management Skills and Housing Affordability}

The relationship between financial management skills and house affordability was studied through correlation and regression analysis. The findings were as summarized in tables 4 to 6

Table 4. Correlation between Financial Management Skills and House Affordability

\begin{tabular}{llc}
\hline & & Affordability of Housing Skills \\
\hline \multirow{3}{*}{ Financial Management Skills } & $\mathrm{R}$ & $0.582^{* *}$ \\
& $\mathrm{p}$-value & 0.000 \\
& $\mathrm{~N}$ & 333 \\
\hline
\end{tabular}

The study revealed significant positive relationship between financial management skills and house affordability. Financial management skills enhance financial decisions and therefore lead to better actions towards long terms investments like home ownership. This implies that, the more informed one is the better he or she in making investment decisions. The current results are in support of the findings by $[15 ; 16]$ further found that there was a significant relationship between financial management skills and housing affordability. High financial management skills led to higher levels of house affordability [1]. 
Table 5. Regression on Financial Management Skills and Housing Affordability

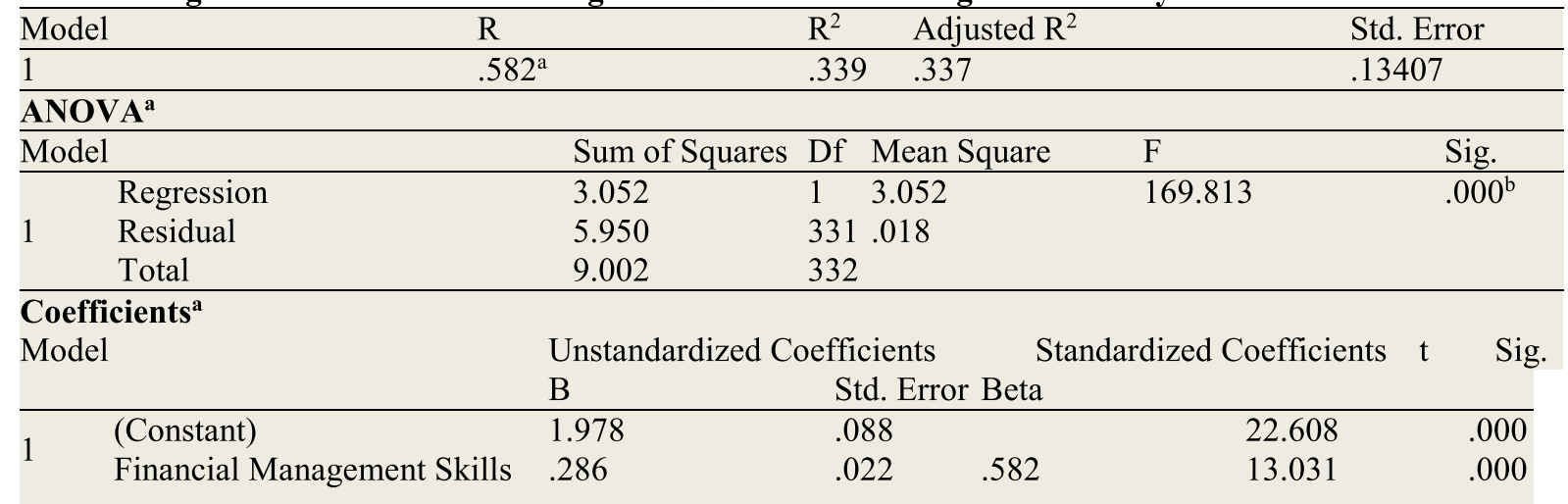

a. Predictors: (Constant), Financial Management Skills

a. Dependent Variable: Affordability

Findings in table 5 indicate that financial management skills are significant determinant of house affordability, accounting for $58.2 \%$ of deviations in house affordability. The model is significant at $\mathrm{p}=0.000$. Similarly, the $\mathrm{t}=13.031, \mathrm{p}=0.000$ indicate that financial management skill is significant determinant of house affordability. Empirical studies $[6 ; 5 ; 10 ; 1]$ indicate that financial management skills enhance affordability of housing.

\subsection{Conclusions and Recommendations}

From the above findings, the study concludes that household heads from low-come backgrounds did not have financial management skills on strategies of savings, skills on how to control expenditures, financial planning skills, knowledge on financial obligations towards acquiring a house, skills on book keeping, skills on examining the cash flows, preparation of budgets for the income, and skills on financial risk analysis. Further, the study revealed that financial management skills are significant determinant of house affordability, and that access to decent and affordable housing can be enhanced through among other factors, enhancing financial management skills among families.

The study concludes that deliberate efforts should be made by family members to enhance financial management skills. The financial institutions and the government can initiate programs to enhance financial management skills, especially among the low income households where such skills are highly inadequate. Further study is recommended to focus on specific knowledge areas and skills that are important in financial management and house affordability, especially for low income households.

\section{References}

1] Ajibola, G. M., Sharafadeen, O., \& Owolabi, B. (2016). Problems and Prospects of Housing Delivery in Osun State, 20(8), 58-64. https://doi.org/10.9790/0837-20855864

2] Akinyode, B. F. (2018). Consumers ' Inclusion for Improving Affordable Housing Delivery in Nigeria. International Journal of Development and Sustainability, 7(3), 1178-1198.

3] Almaden, C. R. (2015). Housing Affordability Challenges : the Case of the Median Income Households in Cagayan de Oro City Philippines College of Arts and Sciences. International Journal of Humanities and Social Science, 4(10), 95-107.

4] Baqutaya, S., Ariffin, A. S., \& Raji, F. (2016). Affordable Housing Policy: Issues and Challenges among Middle-Income Groups, (June). https://doi.org/10.7763/IJSSH.2016.V6.686

5] Baqutayan, S. (2016). Is Affordable Housing an Issue? A Case Study of Housing Stress among MiddleIncome Group In Malaysia. International and Multidisciplinary Journal of Social Sciences, 5(1), $26-50$.

6] Berry, M., Williams, P., Berry, M., Whitehead, C., Williams, P., \& Yates, J. (2016). Financing Affordable Housing: A Critical Comparative Review of the United Kingdom and Australia authored by Financing Affordable Housing: A Critical Comparative Review of the United Kingdom and Australia authored by. Affordable Housing, 1(December 2016), 1-54.

7] Bhattacherjee, A. (2012). Social Science Research: Principles, Methods, and Practices (2nd ed.). USF Tampa Bay Open Access Textbooks Collection.

8] Citibank. (2019). Financial Management Essentials. Financial Managements Essentials for the Entrepreneur, 1(1), 1-25.

9] Central Bank of Kenya. (2018). The Impact of Interest Rate Capping on the Kenya Economy.

10] Huisamen, A., \& Weyers, M. (2016). Teaching employees money management skills and showing a profit in the process: Lessons from a financial literacy course, 1(January 2015), 1-65. 
https://doi.org/10.15270/45-4-194

11] Mugenda, O. (2003). Research Methods: Quantitative and Qualitative Approaches. Nairobi: Acts Press.

12] Mugenda, O., \& Mugenda, A. (2009). Research Methods: Qualitative, Quantitative \& Mixed Methods Approaches (3rd ed.). Nairobi: Africa Centre for Transformative and Inclusive Leadership (ACTIL).

13] Mutisya, K. R. (2015). Urban housing affordability in Kenya A case study of the mortgage housing sector in Nairobi. Department of Real Estate and Construction Management, School of the Built Environment, University of Nairobi, 6(8), 178-187.

14] Mutisya, K. R. (2016). Urban housing affordability in Kenya A case study of the mortgage housing sector in Nairobi. University of Nairobi,.

15] Ojera, P. B. (2019). Indigenous Financial Management Practices in Africa: A Guide for Educators and Practitioners : A Guide for Educators and Practitioners Indigenous Management Practices in Africa Article information: Indigenous Managemnet Practices in Africa, 1(August 2018), 1-28. https://doi.org/10.1108/S1877-636120180000020005

16] Olugbenga, T. D., Yusoff, N., Aziz, N. A., \& Baba, A. N. (2017). Unleashing the Potentials of Housing Sector in Nigeria as Perceived by Users, 4(3), 172-179. https://doi.org/10.11113/ijbes.v4.n3.210

17] Oomen, J., \& Mcallister, P. (2017). The Role of Financial Education in Improved Housing. At Habitat for Humanity, 1(1), 1-54.

18] World Economic Forum. (2019). Making Affordable Housing a Reality in Cities. World Economic Forum, 1(June), 1-60. 